\title{
Investigation of $\mathrm{GdBaCo}_{2-x} \mathrm{Fe}_{x} \mathrm{O}_{6-\delta}(x=0,0.2)-\mathrm{Ce}_{0.8} \mathrm{Sm}_{0.2} \mathrm{O}_{2}$ composite cathodes for intermediate temperature solid oxide fuel cells
}

\author{
N.S. Tsvetkova, A.Yu. Zuev, D.S. Tsvetkov* \\ Department of Chemistry, Institute of Natural Sciences, Ural Federal University, Lenin Av. 51, 620000 Ekaterinburg, Russia
}

\section{H I G H L I G H T S}

- Partial substitution of Fe for Co decreases reactivity of $\mathrm{GdBaCO}_{2-x} \mathrm{Fe}_{x} \mathrm{O}_{6-\delta}$ with $\mathrm{Ce}_{0.8} \mathrm{Sm}_{0.2} \mathrm{O}_{2}$.

- Polarization resistance of cathodes studied significantly depends on firing temperature.

- Certain $\mathrm{Ce}_{0.8} \mathrm{Sm}_{0.2} \mathrm{O}_{2}$ concentration in composites improves their electrochemical performance.

\section{A R T I C L E I N F O}

\section{Article history:}

Received 25 March 2013

Received in revised form 18 May 2013

Accepted 7 June 2013

Available online 14 June 2013

\section{Keywords:}

IT-SOFC

Polarization resistance

Double perovskite

Composite cathode

Thermal expansion

Total conductivity

\begin{abstract}
A B S T R A C T
The double perovskites $\mathrm{GdBaCo}_{2-x} \mathrm{Fe}_{x} \mathrm{O}_{6-\delta}(x=0,0.2)$ and composites $(100-y) \mathrm{GdBaCo}_{2-x} \mathrm{Fe}_{x} \mathrm{O}_{6}$ ${ }_{-\delta}(x=0,0.2)-y \mathrm{Ce}_{0.8} \mathrm{Sm}_{0.2} \mathrm{O}_{2}(y=10-50$ wt.\%) were investigated as cathode materials for intermediate temperature solid oxide fuel cells (IT-SOFCs). Chemical compatibility of $\mathrm{GdBaCO}_{2-x} \mathrm{Fe}_{x} \mathrm{O}_{6-\delta}(x=0,0.2)$ with solid electrolyte $\mathrm{Ce}_{0.8} \mathrm{Sm}_{0.2} \mathrm{O}_{2}$, thermal expansion, DC conductivity and electrochemical performance of $(100-y) \mathrm{GdBaCo}_{2-x} \mathrm{Fe}_{x} \mathrm{O}_{6-\delta}(x=0,0.2)-y \mathrm{Ce}_{0.8} \mathrm{Sm}_{0.2} \mathrm{O}_{2}(y=10-50$ wt.\%) were studied. Partial substitution of $\mathrm{Fe}$ for $\mathrm{Co}$ was shown to lead to decrease of double perovskite $\mathrm{GdBaCo}_{2-\chi} \mathrm{Fe}_{x} \mathrm{O}_{6}$ ${ }_{-\delta} \delta$ reactivity with the solid electrolyte $\mathrm{Ce}_{0.8} \mathrm{Sm}_{0.2} \mathrm{O}_{2}$. Polarization resistance of cathodes studied was found to depend significantly on firing temperature. Variation of solid electrolyte content in $(100-y)$ $\mathrm{GdBaCo}_{2-x} \mathrm{Fe}_{x} \mathrm{O}_{6-\delta}(x=0,0.2)-y \mathrm{Ce}_{0.8} \mathrm{Sm}_{0.2} \mathrm{O}_{2}(y=10-50$ wt.\%) composites was shown to allow to optimize their electrochemical performance. Cathode materials of 80 wt.\% $\mathrm{GdBaCo}_{2} \mathrm{O}_{6-\delta}-20 \mathrm{wt} . \%$ $\mathrm{Ce}_{0.8} \mathrm{Sm}_{0.2} \mathrm{O}_{2}$ and 65 wt.\% $\mathrm{GdBaCo}_{1.8} \mathrm{Fe}_{0.2} \mathrm{O}_{6-\delta}-35$ wt.\% $\mathrm{Ce}_{0.8} \mathrm{Sm}_{0.2} \mathrm{O}_{2}$ were found to have the lowest polarization resistances and reasonable values of thermal expansion coefficient (TEC) and, therefore, can be considered as promising cathode materials for IT-SOFCs.
\end{abstract}

(c) 2013 Elsevier B.V. All rights reserved.

\section{Introduction}

In the past few decades solid oxide fuel cells (SOFCs) have attracted great attention as alternative power generation devices with high working efficiency and environmental safety. Operating temperature lowering is to be general way to enlarge commercial application of SOFCs due to increase of number of construction materials and their life-time and, as a consequence, reduced cost of energy production.

Double perovskites with general formula $R \mathrm{BaCO}_{2} \mathrm{O}_{6-\delta}(R$-rareearth element) are considered as promising cathode materials for IT-SOFCs [1-6]. The defect structure of these compounds is of key importance for understanding their properties such as relatively

\footnotetext{
* Corresponding author. Tel.: +7 343251 7927; fax: +7 3432615978.

E-mail address: Dmitrii.Tsvetkov@usu.ru (D.S. Tsvetkov).
}

fast oxygen transport, high mixed ionic-electronic conductivity and high electrocatalytic activity with respect to reaction of oxygen reduction [7-10].

Despite great number of publications devoted to study of electrical conductivity, thermal expansion and electrochemical performance of double perovskites $\mathrm{RBaCO}_{2} \mathrm{O}_{6-\delta}[3,5,11-21,23]$ the available experimental data vary significantly from paper to paper. For example, the maximum conductivity value for $\mathrm{GdBaCo}_{2} \mathrm{O}_{6-\delta}$ was found [3] to be equal to $620 \mathrm{~S} \cdot \mathrm{cm}^{-1}$ as against $400 \mathrm{~S} \cdot \mathrm{cm}^{-1}$ according to Ref. [11]. Significant scattering of polarization resistance values reported for $R \mathrm{BaCo}_{2} \mathrm{O}_{6-\delta}(R=\mathrm{Pr}, \mathrm{Sm}, \mathrm{Gd})$ [3-6,12-18] also should be mentioned. In addition, possible influence of solid electrolyte material on the electrochemical performance of composite cathodes based on $R \mathrm{BaCo}_{2} \mathrm{O}_{6-\delta}(R=\mathrm{Pr}, \mathrm{Nd}, \mathrm{Sm}, \mathrm{Gd})$ still remains controversial topic $[5,12,14,16,19-21]$. For instance, polarization resistance of the composite cathode $\mathrm{GdBaCo}_{2} \mathrm{O}_{6-\delta}-$ $\mathrm{Ce}_{0.8} \mathrm{Gd}_{0.2} \mathrm{O}_{1.9}$ increases with solid electrolyte content and exceeds 
that of pure $\mathrm{GdBaCo}_{2} \mathrm{O}_{6-\delta}$ cathode according to Refs. [12,19] whereas opposite results are reported in Refs. [14,21].

Therefore, the priority aims of the present work were (i) to investigate chemical compatibility of double perovskites $\mathrm{GdBaCo}_{2-x} \mathrm{Fe}_{x} \mathrm{O}_{6-\delta}(x=0 ; 0.2)$ with solid electrolyte $\mathrm{Ce}_{0.8} \mathrm{Sm}_{0.2} \mathrm{O}_{2}$, (ii) to measure thermal expansion coefficient and overall conductivity of cathode materials $(100-y) \mathrm{GdBaCo}_{2-x} \mathrm{Fe}_{x} \mathrm{O}_{6-\delta}(x=0 ; 0.2)$ $-y \mathrm{Ce}_{0.8} \mathrm{Sm}_{0.2} \mathrm{O}_{2}(y=0-50 \mathrm{wt} . \%)$ and (iii) to determine polarization resistance of identically prepared $(100-y) \mathrm{GdBaCo}_{2-x} \mathrm{Fe}_{x} \mathrm{O}_{6-\delta}$ $(x=0 ; 0.2)-y \mathrm{Ce}_{0.8} \mathrm{Sm}_{0.2} \mathrm{O}_{2}(y=0-50$ wt.\%) composite cathodes as a function of $\mathrm{Ce}_{0.8} \mathrm{Sm}_{0.2} \mathrm{O}_{2-\delta}$ content.

\section{Experimental}

Powder samples of double perovskites $\mathrm{GdBaCo}_{2-x} \mathrm{Fe}_{x} \mathrm{O}_{6-\delta}(x=0$, 0.2 ) and solid electrolyte $\mathrm{Ce}_{0.8} \mathrm{Sm}_{0.2} \mathrm{O}_{2}$ were prepared by means of glycerol-nitrate method using $\mathrm{Gd}_{2} \mathrm{O}_{3}, \mathrm{BaCO}_{3}, \mathrm{Co}, \mathrm{FeC}_{2} \mathrm{O}_{4} \cdot 2 \mathrm{H}_{2} \mathrm{O}$, $\mathrm{Ce}\left(\mathrm{NO}_{3}\right)_{3} \cdot 6 \mathrm{H}_{2} \mathrm{O}, \mathrm{Sm}_{2} \mathrm{O}_{3}$ as starting materials. All materials used had a purity of $99.99 \%$.

Stoichiometric mixture of starting materials was dissolved in concentrated nitric acid (99.99\% purity) and required volume of glycerol (99\% purity) was added as a complexing agent and a fuel. Glycerol quantity was calculated according to full reduction of corresponding nitrates to molecular nitrogen $\mathrm{N}_{2}$. As prepared solution was heated continuously at $100{ }^{\circ} \mathrm{C}$ until water evaporation and pyrolysis of the dried precursor. In case of $\mathrm{GdBaCo}_{2-x} \mathrm{Fe}_{x} \mathrm{O}_{6-\delta}$ $(x=0,0.2)$ synthesis the resulting ash was subsequently calcined at 700 and $900{ }^{\circ} \mathrm{C}$ for $12 \mathrm{~h}$ in air with careful intermediate regrinding to get the desired double perovskite powder. The $\mathrm{Ce}_{0.8} \mathrm{Sm}_{0.2} \mathrm{O}_{2}$ powder was obtained by calcining the ash after pyrolysis at $1100{ }^{\circ} \mathrm{C}$ for $12 \mathrm{~h}$ in air.

The phase composition of powder samples prepared accordingly was investigated by means of X-Ray diffraction (XRD) with Equinox 3000 diffractometer (Inel, France). The XRD showed no indication for the presence of a second phase.

The chemical composition of all objects under investigation was preliminary checked using ICP spectrometer ICAP 6500 DUO and atomic absorption spectrometer Solaar M6, Thermo Scientific, USA. All samples used for measurements were shown to have the stoichiometric composition within the accuracy of $2 \%$. No impurities were found within the same accuracy range as well.

Composite cathode materials $(100-y) \mathrm{GdBaCo}_{2-x} \mathrm{Fe}_{x} \mathrm{O}_{6-\delta}$ $(x=0 ; 0.2)-y \mathrm{Ce}_{0.8} \mathrm{Sm}_{0.2} \mathrm{O}_{2}((100-y) \mathrm{GBC}(\mathrm{F} 02)-y \mathrm{SDC})$ were prepared by mechanical mixing of $\mathrm{GdBaCO}_{2-x} \mathrm{Fe}_{x} \mathrm{O}_{6-\delta}$ (GBC(F02)) and $\mathrm{Ce}_{0.8} \mathrm{Sm}_{0.2} \mathrm{O}_{2}$ (SDC) powders in different weight ratios within the range $10 \leq y$, wt.\% $\leq 50$. The powders of cathode and electrolyte materials were mixed in ethanol using agate mortar and pestle.

The chemical compatibility of GBC(F02) and SDC was studied by means of homogenizing annealing of 50:50 (wt.\%) mixtures at different temperatures in the temperature range between 900 and $1200{ }^{\circ} \mathrm{C}$ for $12 \mathrm{~h}$ in air followed by XRD analysis.

For electrical conductivity and thermal expansion measurements rectangular bars of $30 \times 3 \times 3 \mathrm{~mm}^{3}$ were prepared by dry pressing at $20 \mathrm{MPa}$ and sintering for $12 \mathrm{~h}$ in air at $1000^{\circ} \mathrm{C}, 1100{ }^{\circ} \mathrm{C}$, and $1300{ }^{\circ} \mathrm{C}$ for composite cathodes, GBCC(F02) and SDC, respectively.

Thermal expansion of the samples prepared accordingly was measured using DIL 402 C dilatometer (Netzsch GmbH, Germany) in the temperature range $30 \leq T,{ }^{\circ} \mathrm{C} \leq 1000$ in air.

Electrical conductivity of the composite cathodes $(100-y)$ $\mathrm{GBC}(\mathrm{F02})-y$ SDC, double perovskites GBC(F02), and solid electrolyte SDC was measured by means of 4-probe dc-method. Experimental setup and technique are described in detail elsewhere [22]. The measurements of electrical conductivity were carried out at temperatures between 30 and $1000^{\circ} \mathrm{C}$ in air.
Polarization resistance was studied by means of electrochemical impedance spectroscopy (EIS) using symmetrical cells

cathode material|SDC|cathode material

Impedance spectra of cell (1) were measured by means of Z500PX impedance analyzer (Elins, Russia) under open circuit conditions with $25 \mathrm{mV}$ amplitude of ac-signal in the ranges $1 \mathrm{~Hz} \leq f \leq 0.5 \mathrm{MHz}$ and $600 \leq T,{ }^{\circ} \mathrm{C} \leq 750$ (with $25^{\circ} \mathrm{C}$ step) of frequency and temperature, respectively. Dense (95\%) electrolyte disks of $20 \mathrm{~mm}$ in diameter and 1-2 $\mathrm{mm}$ in thickness for cell (1) were fabricated by dry pressing at $20 \mathrm{MPa}$ and sintering at $1300{ }^{\circ} \mathrm{C}$ for $24 \mathrm{~h}$ in air. Powders of cathode materials were dispersed in ethanol solution of polyvinylbutyral (5 wt.\%). The resultant slurry was symmetrically screen-printed onto opposite surfaces of the electrolyte disk and fired at different temperatures in the range between 950 and $1100{ }^{\circ} \mathrm{C}$ (with $50{ }^{\circ} \mathrm{C}$ step) for $6 \mathrm{~h}$ in air to form a single cell (1). Impedance spectra were analyzed with ZView 2.0 software (Scribner Associates Inc., U.S.A.).

\section{Results and discussion}

The results of chemical compatibility study are shown in Fig. 1. As seen solid state reaction between GBC(F02) and SDC occurs at temperatures above $1050{ }^{\circ} \mathrm{C}$ and $1100{ }^{\circ} \mathrm{C}$ for GBC and GBCF02, respectively. $\mathrm{BaCoO}_{3}$ and $\mathrm{Co}_{3} \mathrm{O}_{4}$ were identified as the products of
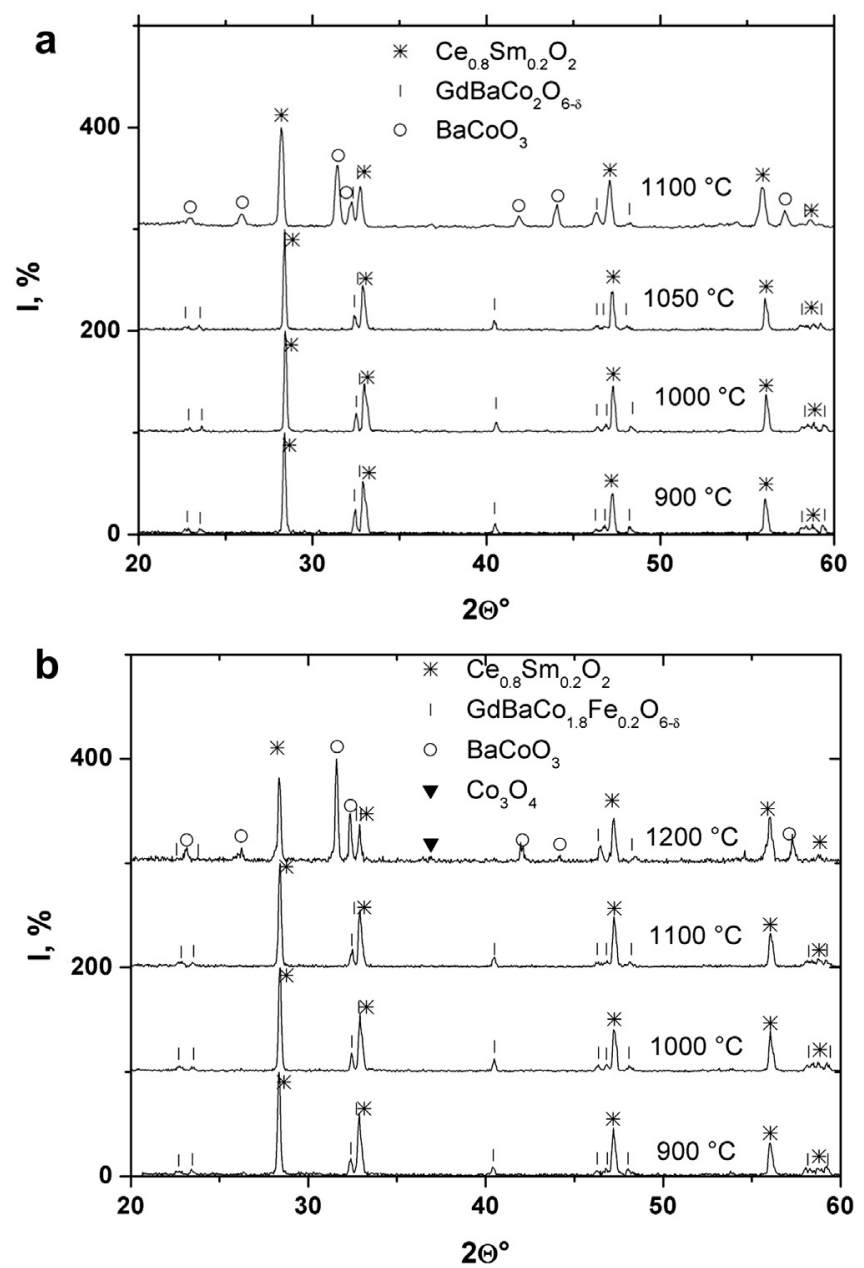

Fig. 1. XRD patterns of mixtures (50:50 wt. \%) calcined at different temperatures for $12 \mathrm{~h}$ in air: (a) $\mathrm{GdBaCo}_{2} \mathrm{O}_{6-\delta}-\mathrm{Ce}_{0.8} \mathrm{Sm}_{0.2} \mathrm{O}_{2}$; (b) $\mathrm{GdBaCo}_{1.8} \mathrm{Fe}_{0.2} \mathrm{O}_{6-\delta}-\mathrm{Ce}_{0.8} \mathrm{Sm}_{0.2} \mathrm{O}_{2}$. 
this interaction. Since the products did not contain gadolinium it was proposed that its dissolution in SDC takes place during the reaction. Shift of the SDC lines in the X-ray pattern (Fig. 1) and, as a consequence, increase of the SDC cell parameters after the reaction with GBC(F02) obviously indicate in favor of such dissolution. Similar change of the SDC cell parameters due to its reaction with GBC was also reported in Ref. [23].

Thermal expansion behavior of $(100-y)$ GBCF02 $-y$ SDC composite materials and solid electrolyte SDC is shown in Fig. 2. The values of average thermal expansion coefficient (TEC) in the temperature range between 30 and $1000^{\circ} \mathrm{C}$ are summarized for all samples studied in Table 1 . As follows the values of TEC measured by us are in good agreement with those reported in literature $[14,21,24]$. Besides, SDC addition leads to TEC value decrease of cathode material and, as a consequence, to elimination in part of a mechanical mismatch between cathode and electrolyte materials. For instance, the TEC value of pure GBCF02 cathode is equal to $20.7 \cdot 10^{-6} \mathrm{~K}^{-1}$ and that of the composite $65 \%$ GBCF02 - 35\% SDC is $17.2 \cdot 10^{-6} \mathrm{~K}^{-1}$. Similar results were reported earlier for composite cathodes based on double perovskites $\mathrm{RBaCO}_{2} \mathrm{O}_{6-\delta}$ with $R=\mathrm{Pr}$, Nd, Sm, Gd [5,14,16,19-21].

Total conductivity of the double perovskites $\mathrm{GBC}(\mathrm{F} 02)$ and composites $(100-y) \mathrm{GBC}(\mathrm{F} 02)-y$ SDC measured in the temperature range between 30 and $1000{ }^{\circ} \mathrm{C}$ in air is shown in Fig. 3. The initial growth of $\mathrm{GBC}(\mathrm{F02})$ total conductivity with temperature in the range $25 \leq T,{ }^{\circ} \mathrm{C} \leq 300$ is caused by simultaneous increase of
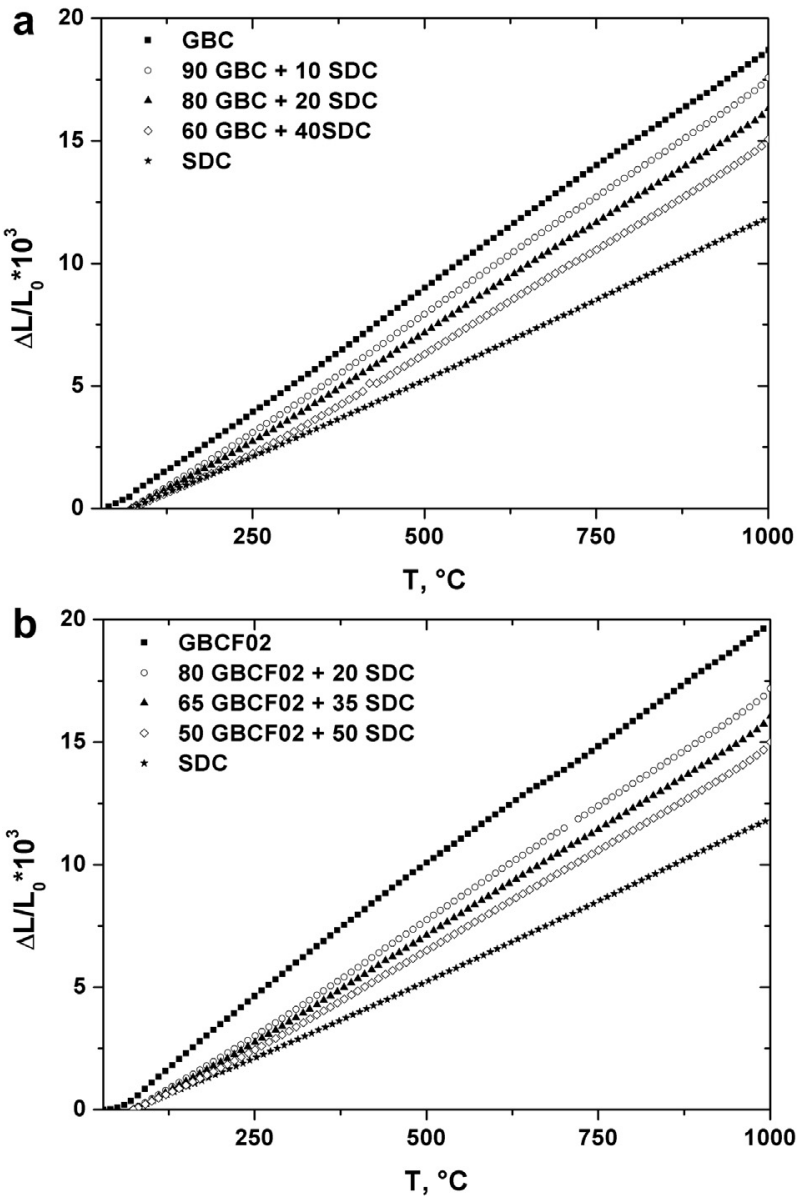

Fig. 2. Thermal expansion in air: (a) $\mathrm{Ce}_{0.8} \mathrm{Sm}_{0.2} \mathrm{O}_{2}$, pure $\mathrm{GdBaCo}_{2} \mathrm{O}_{6-\delta}$ and composites $(100-y) \mathrm{GdBaCo}_{2} \mathrm{O}_{6-\delta}-y \mathrm{Ce}_{0.8} \mathrm{Sm}_{0.2} \mathrm{O}_{2}\left(y=10,20,40\right.$ wt. \%); (b) $\mathrm{Ce}_{0.8} \mathrm{Sm}_{0.2} \mathrm{O}_{2}$, pure $\mathrm{GdBaCo}_{1.8} \mathrm{Fe}_{0.2} \mathrm{O}_{6-\delta}$ and composites $(100-y) \mathrm{GdBaCo}_{1.8} \mathrm{Fe}_{0.2} \mathrm{O}_{6-\delta}-y \quad \mathrm{Ce}_{0.8} \mathrm{Sm}_{0.2} \mathrm{O}_{2}$ $(y=20,35,50$ wt. \%).
Table 1

Average TEC values of the $\mathrm{Ce}_{0.8} \mathrm{Sm}_{0.2} \mathrm{O}_{2}$ electrolyte and the $(100-y)$ $\mathrm{GdBaCo}_{2-x} \mathrm{Fe}_{x} \mathrm{O}_{6-\delta}(x=0,0.2)-y \mathrm{Ce}_{0.8} \mathrm{Sm}_{0.2} \mathrm{O}_{2}(y=0-50$ wt.\%) cathode materials over the temperature range $30-1000{ }^{\circ} \mathrm{C}$.

\begin{tabular}{lll}
\hline Material & \multicolumn{1}{l}{ TEC, $10^{-6} \mathrm{~K}^{-1}$} \\
\cline { 2 - 3 } & This work & Literature \\
\hline $\mathrm{GdBaCo}_{2} \mathrm{O}_{6-\delta}$ & 19.8 & $20.1[21] ;$ \\
& & $20.0[14]$ \\
$90 \mathrm{GdBaCo}_{2} \mathrm{O}_{6-\delta}-10 \mathrm{Ce}_{0.8} \mathrm{Sm}_{0.2} \mathrm{O}_{2}$ & 19.0 & $19.0[14]$ \\
$80 \mathrm{GdBaCo}_{2} \mathrm{O}_{6-\delta}-20 \mathrm{Ce}_{0.8} \mathrm{Sm}_{0.2} \mathrm{O}_{2}$ & 17.7 & - \\
$60 \mathrm{GdBaCo}_{2} \mathrm{O}_{6-\delta}-40 \mathrm{Ce}_{0.8} \mathrm{Sm}_{0.2} \mathrm{O}_{2}$ & 16.4 & $15.63[21]$ \\
$\mathrm{GdBaCo}_{1.8} \mathrm{Fe}_{0.2} \mathrm{O}_{6-\delta}$ & 20.7 & - \\
$80 \mathrm{GdBaCo}_{1.8} \mathrm{Fe}_{0.2} \mathrm{O}_{6-\delta}-20 \mathrm{Ce}_{0.8} \mathrm{Sm}_{0.2} \mathrm{O}_{2}$ & 18.5 & - \\
$65 \mathrm{GdBaCo}_{1.8} \mathrm{Fe}_{0.2} \mathrm{O}_{6-\delta}-35 \mathrm{Ce}_{0.8} \mathrm{Sm}_{0.2} \mathrm{O}_{2}$ & 17.2 & - \\
$50 \mathrm{GdBaCo}_{1.8} \mathrm{Fe}_{0.2} \mathrm{O}_{6-\delta}-50 \mathrm{Ce}_{0.8} \mathrm{Sm}_{0.2} \mathrm{O}_{2}$ & 16.1 & - \\
$\mathrm{Ce}_{0.8} \mathrm{Sm}_{0.2} \mathrm{O}_{2}$ & 12.9 & $12.0[24]$ \\
\hline
\end{tabular}

mobility of the localized electrons and holes as well as their concentration [25]. The latter occurs due to thermally activated $\mathrm{Co}^{3+}$ disproportionation $\left(2 \mathrm{Co}^{+3}=\mathrm{Co}^{+2}+\mathrm{Co}^{+4}\right)$.

Total conductivity decrease observed in Fig. 3 at temperatures higher than $400{ }^{\circ} \mathrm{C}$ can be explained taking into account release of oxygen by the oxide lattice at elevated temperatures. Really onset of lattice oxygen release was shown in Ref. [25] to correspond to
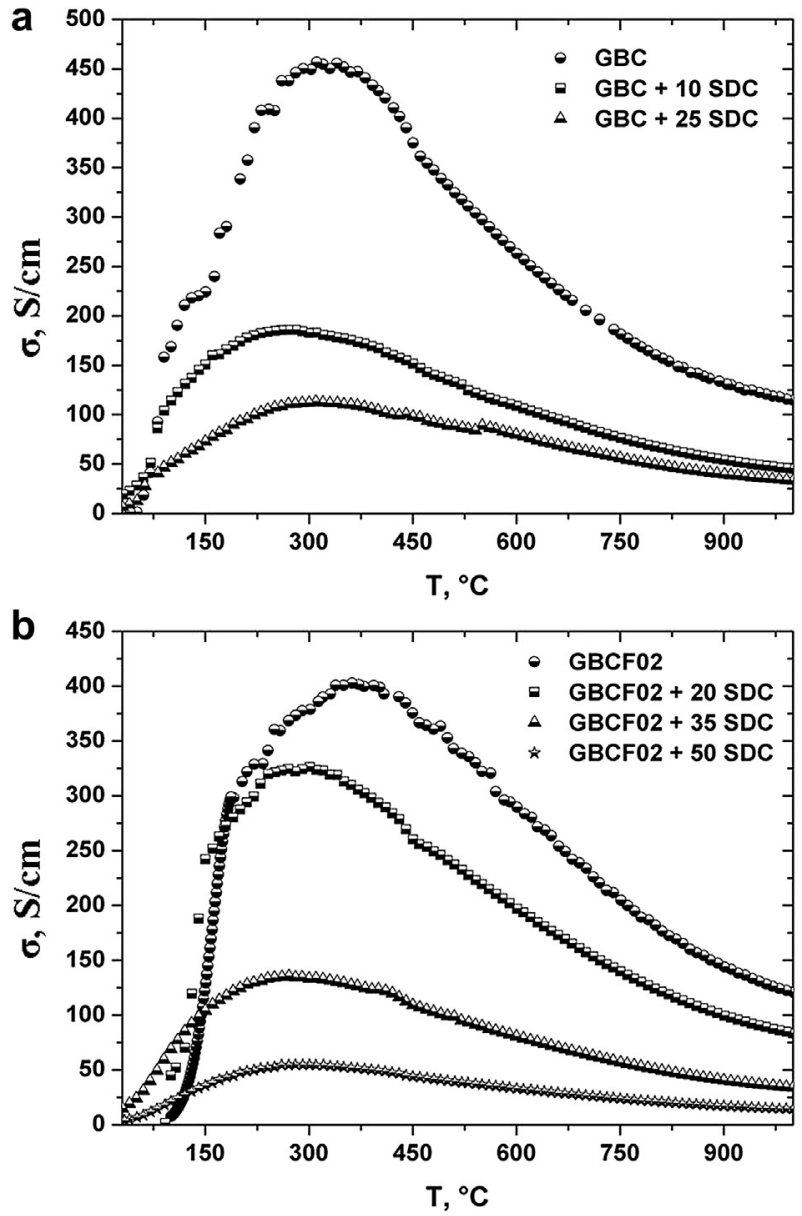

Fig. 3. Temperature dependences of $D C$ conductivity at $30-1000{ }^{\circ} \mathrm{C}$ in air: (a) pure $\mathrm{GdBaCO}_{2} \mathrm{O}_{6-\delta}$ and composites $(100-y) \mathrm{GdBaCo}_{2} \mathrm{O}_{6-\delta}-y \mathrm{Ce}_{0.8} \mathrm{Sm}_{0.2} \mathrm{O}_{2}(y=10,25 \mathrm{wt}$. \%); (b) pure $\mathrm{GdBaCo}_{1.8} \mathrm{Fe}_{0.2} \mathrm{O}_{6-\delta}$ and composites (100 - y) $\mathrm{GdBaCo}_{1.8} \mathrm{Fe}_{0.2} \mathrm{O}_{6-\delta}-y$ $\mathrm{Ce}_{0.8} \mathrm{Sm}_{0.2} \mathrm{O}_{2} \quad\left(y=20,35,50\right.$ wt. \%). $\mathrm{GBC} \equiv \mathrm{GdBaCO}_{2} \mathrm{O}_{6-\delta} ; \quad \mathrm{GBCF02} \equiv$ $\mathrm{GdBaCo}_{1.8} \mathrm{Fe}_{0.2} \mathrm{O}_{6-\delta} ; \mathrm{SDC} \equiv \mathrm{Ce}_{0.8} \mathrm{Sm}_{0.2} \mathrm{O}_{2}$. 
temperature of about $400{ }^{\circ} \mathrm{C}$ for both GBC and GBCF02. The concentration of localized holes decreases and simultaneously one of electrons increases as a result. Therefore, total conductivity decrease mentioned above is most likely caused by the corresponding decrease of concentration of holes as major charge carriers. Hole mobility was shown by us earlier [8] to be 8 times larger than that of electrons. The maximum conductivity of GBC comes to value of $450 \mathrm{~S} \cdot \mathrm{cm}^{-1}$ (see Fig. 3), which is quite comparable with one of $400 \mathrm{~S} \cdot \mathrm{cm}^{-1}$ reported by Peña-Martínez et al. [11]. As seen in Fig. 3 addition of SDC electrolyte significantly decreases total conductivity of the composite cathodes as compared to undoped $\mathrm{GBC}(\mathrm{F02})$. Similar trend was also observed for $\mathrm{PrBaCO}_{2} \mathrm{O}_{6-\delta}-$ $\mathrm{Ce}_{0.8} \mathrm{Sm}_{0.2} \mathrm{O}_{1.9}$ composites [16].

Typical impedance spectrum of the cell (1) measured for GBCF02 cathode at $700{ }^{\circ} \mathrm{C}$ in air is shown, as an example, in Fig. 4.

Equivalent scheme used for analysis is also given in Fig. 4. Polarization resistance of cathodes studied was determined as segment between low and high frequency cutoffs on the real impedance axis. In other words, polarization resistance is equal to $R_{2}+R_{3}$ (see Fig. 4). This polarization resistance corresponds to the sum of the polarization resistances of the two electrodes of the cell (1). Therefore, a cathode polarization resistance normalized to an active area (ASR) can be calculated as following

$\mathrm{ASR}=\frac{\left(R_{2}+R_{3}\right) S}{2}$

where $S$ is an area $\left(\mathrm{cm}^{2}\right)$ of electrode.

The influence of firing temperature on the polarization resistance of the double perovskite cathodes is shown in Fig. 5. Firing temperature seems to define the microstructure of cathode layer effecting its surface area, porosity, particle connection as well as adherence to the electrolyte layer. Electrode particles formed at low firing temperature are believed to be weakly connected with each other and physical contact between the cathode and electrolyte layers is insufficient. As a result, a relatively large electrode polarization resistance can be expected. Increase of firing temperature allows improving the electrode performance. However, too high firing temperature may decrease cathode porosity and number of active sites for adsorption, dissociation, and surface diffusion of oxygen. As a result, one can expect increasing electrode polarization resistance. Therefore, the optimum value of a cathode firing temperature has to provide a compromise between two opposite

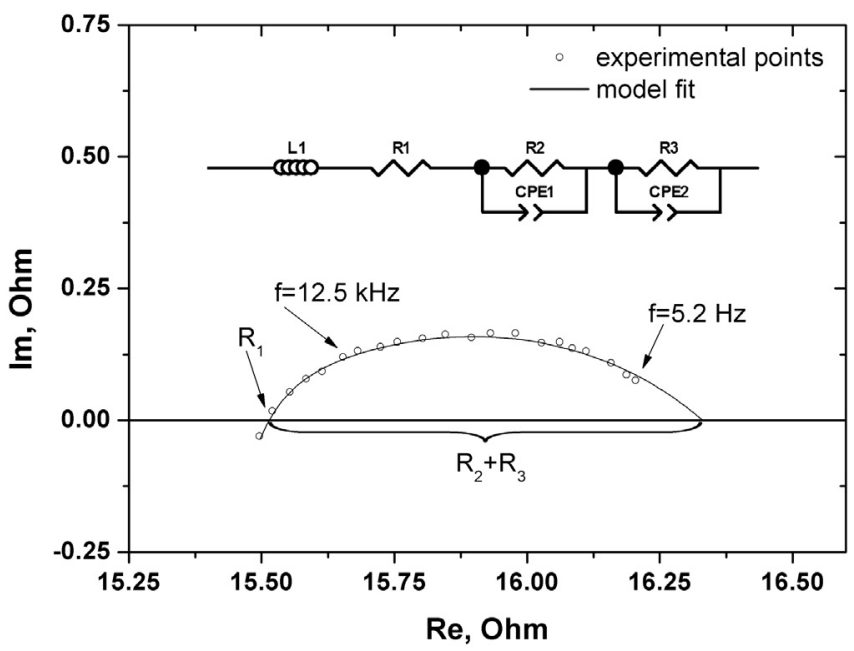

Fig. 4. Typical impedance spectrum and equivalent circuit of symmetrical cell $\mathrm{GdBaCo}_{1.8} \mathrm{Fe}_{0.2} \mathrm{O}_{6-\delta}\left|. \mathrm{Ce}_{0.8} \mathrm{Sm}_{0.2} \mathrm{O}_{2}\right| . \mathrm{GdBaCo}_{1.8} \mathrm{Fe}_{0.2} \mathrm{O}_{6-\delta}$ at $700{ }^{\circ} \mathrm{C}$
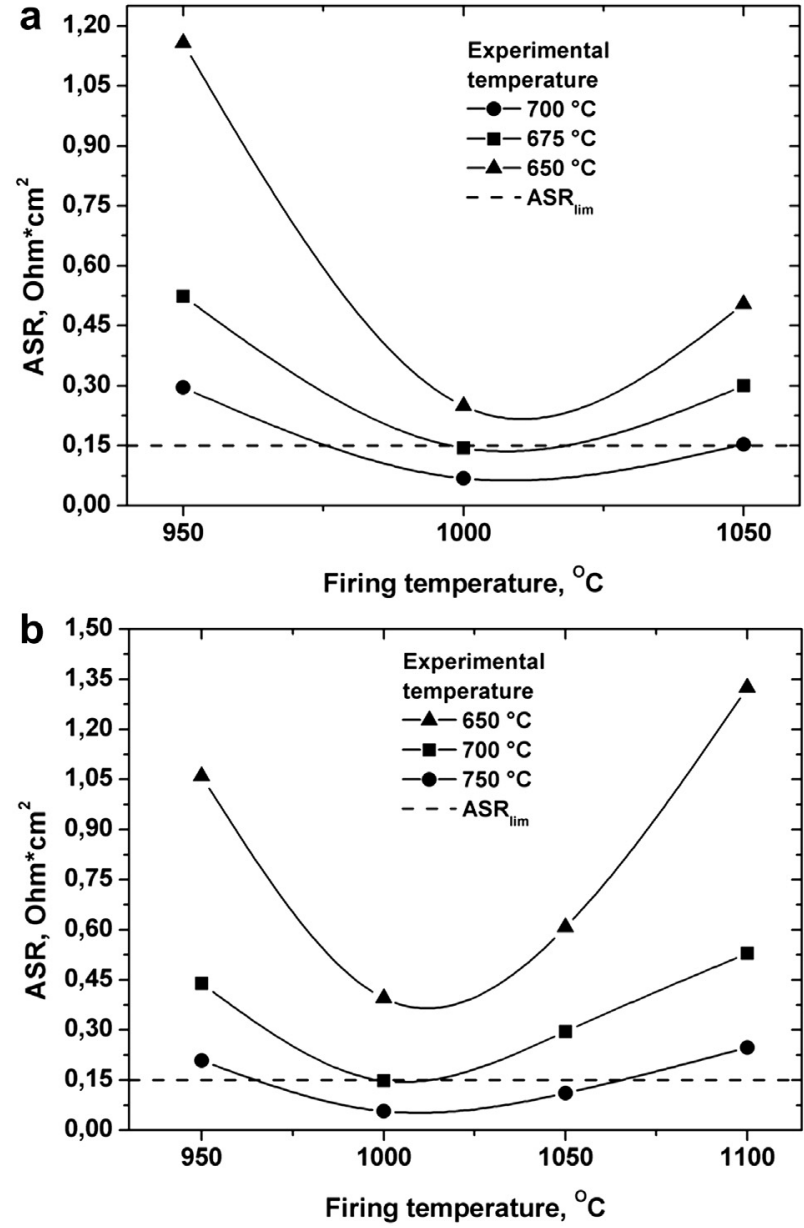

Fig. 5. ASR of cathodes vs. firing temperature of cathode layer on $\mathrm{Ce}_{0.8} \mathrm{Sm}_{0.2} \mathrm{O}_{2}$ electrolyte: (a) $\mathrm{GdBaCo}_{2} \mathrm{O}_{6-\delta}$; (b) $\mathrm{GdBaCo}_{1.8} \mathrm{Fe}_{0.2} \mathrm{O}_{6-\delta}$.

operating factors and, as a consequence, enables reasonable physical contact between cathode layer and electrolyte as well as the extensive porous microstructure. As seen in Fig. 5 the optimum firing temperature for the double perovskite cathodes is around $1000{ }^{\circ} \mathrm{C}$ since the lowest polarization resistance of both GBC and GBCF02 corresponds to this firing temperature and reaches the target value of ASR $\left(0.15 \mathrm{Ohm} \cdot \mathrm{cm}^{2}\right)$ at operating temperatures of $675^{\circ} \mathrm{C}$ and $700{ }^{\circ} \mathrm{C}$, respectively.

Arrhenius plots of the ASR determined for GBC(F02) cathodes fired at $1000^{\circ} \mathrm{C}$ are shown in Fig. 6 . The increase of the polarization resistance with iron-doping is clearly seen in this figure. Aforementioned increase is most likely caused by the difference in oxide ion conductivity of the undoped and iron-doped double perovskites. Substitution of iron for cobalt was shown recently [26] to lead to some decrease of oxide ion conductivity in $\mathrm{GBC}(\mathrm{F} 02)$.

The ASR of composite cathodes $(100-y)$ GBC(F02) $-y$ SDC $(y=0.1-0.5)$ is shown in Figs. 7 and 8 as a function of temperature and SDC content, respectively. As seen the polarization resistance of composite cathode materials reaches its minimum at certain concentration of SDC electrolyte. This observation is in agreement with data reported in Refs. $[5,14,16,18,20]$ for composites consisting of double perovskites $R \mathrm{BaCO}_{2} \mathrm{O}_{6-\delta}(R=\mathrm{Pr}, \mathrm{Sm}, \mathrm{Gd})$ and $\mathrm{CeO}_{2}$ - based solid electrolyte. Such change of the ASR with SDC content enables improvement of the electrochemical characteristic of cathodes based on the double perovskite $\mathrm{GBC}(\mathrm{FO2})$ as well as decreasing working temperature of IT-SOFC. 
$\mathrm{T},{ }^{\circ} \mathrm{C}$

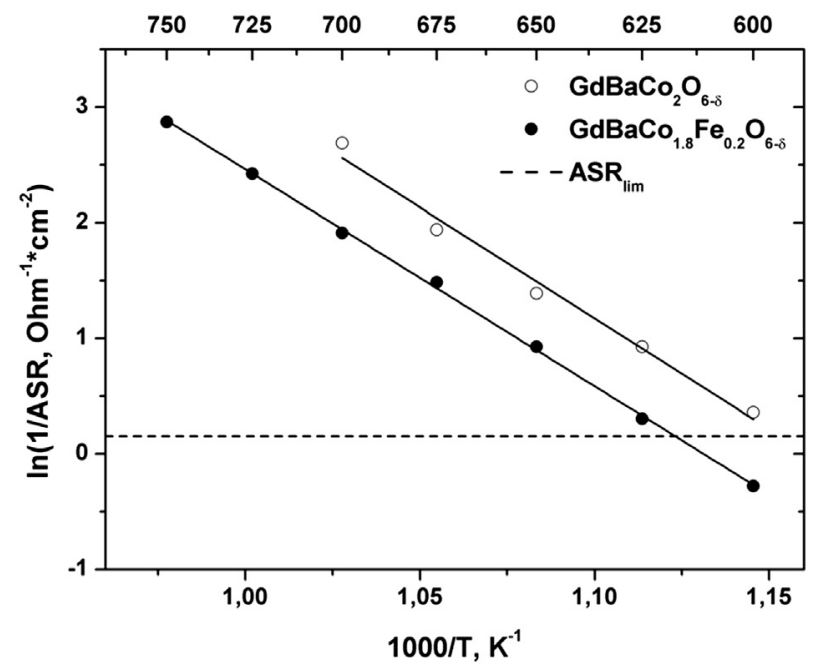

Fig. 6. Arrhenius plots of $\mathrm{ASR}$ of $\mathrm{GdBaCO}_{2} \mathrm{O}_{6-\delta}$ and $\mathrm{GdBaCo}_{1.8} \mathrm{Fe}_{0.2} \mathrm{O}_{6-\delta}$ cathodes fired at $1000{ }^{\circ} \mathrm{C}$.
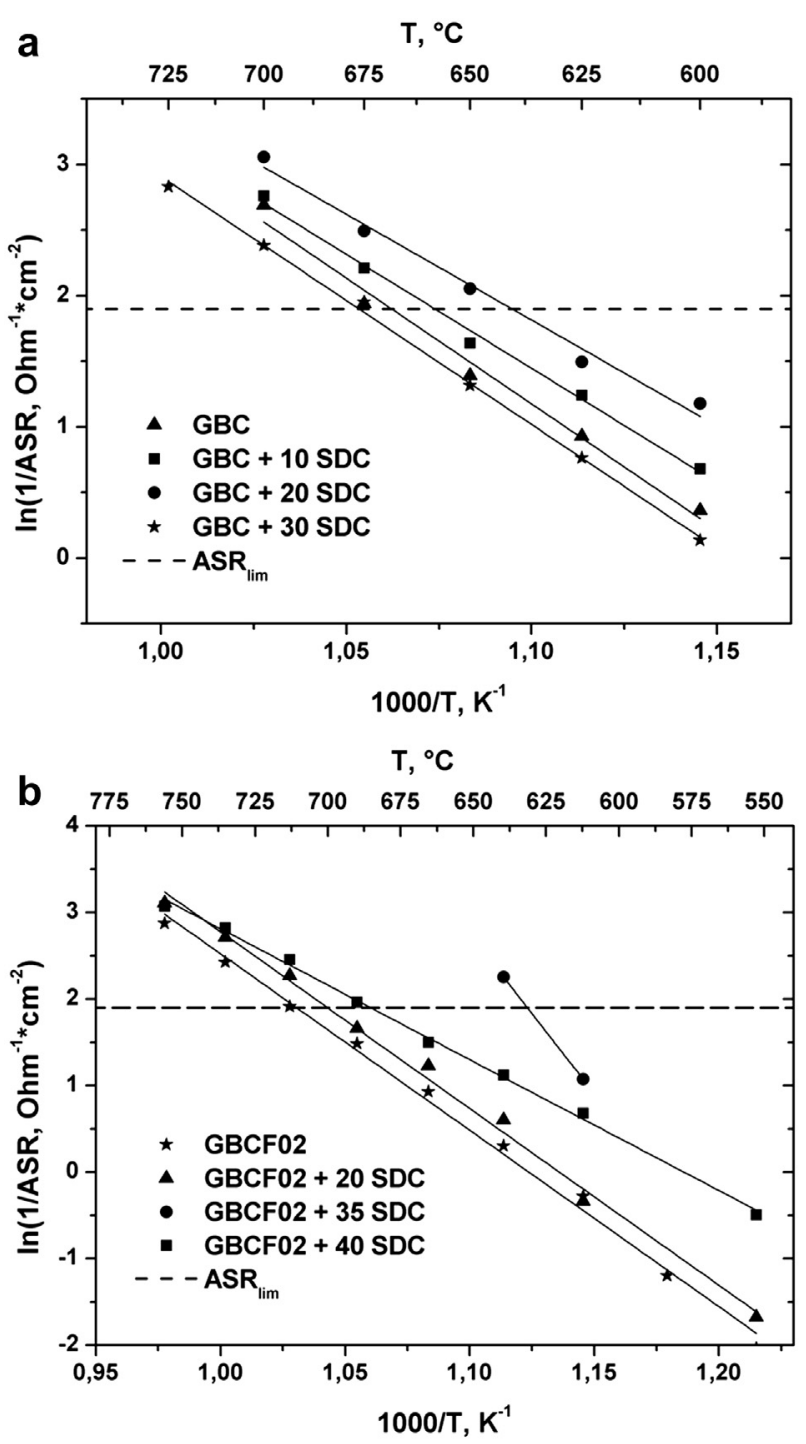

Fig. 7. Arrhenius plots of ASR of composite cathodes: (a) $(100-y) \mathrm{GdBaCo}_{2} \mathrm{O}_{6-\delta}-y$ $\mathrm{Ce}_{0.8} \mathrm{Sm}_{0.2} \mathrm{O}_{2}$; (b) $(100-y) \mathrm{GdBaCo}_{1.8} \mathrm{Fe}_{0.2} \mathrm{O}_{6-\delta}-y \mathrm{Ce}_{0.8} \mathrm{Sm}_{0.2} \mathrm{O}_{2}$.
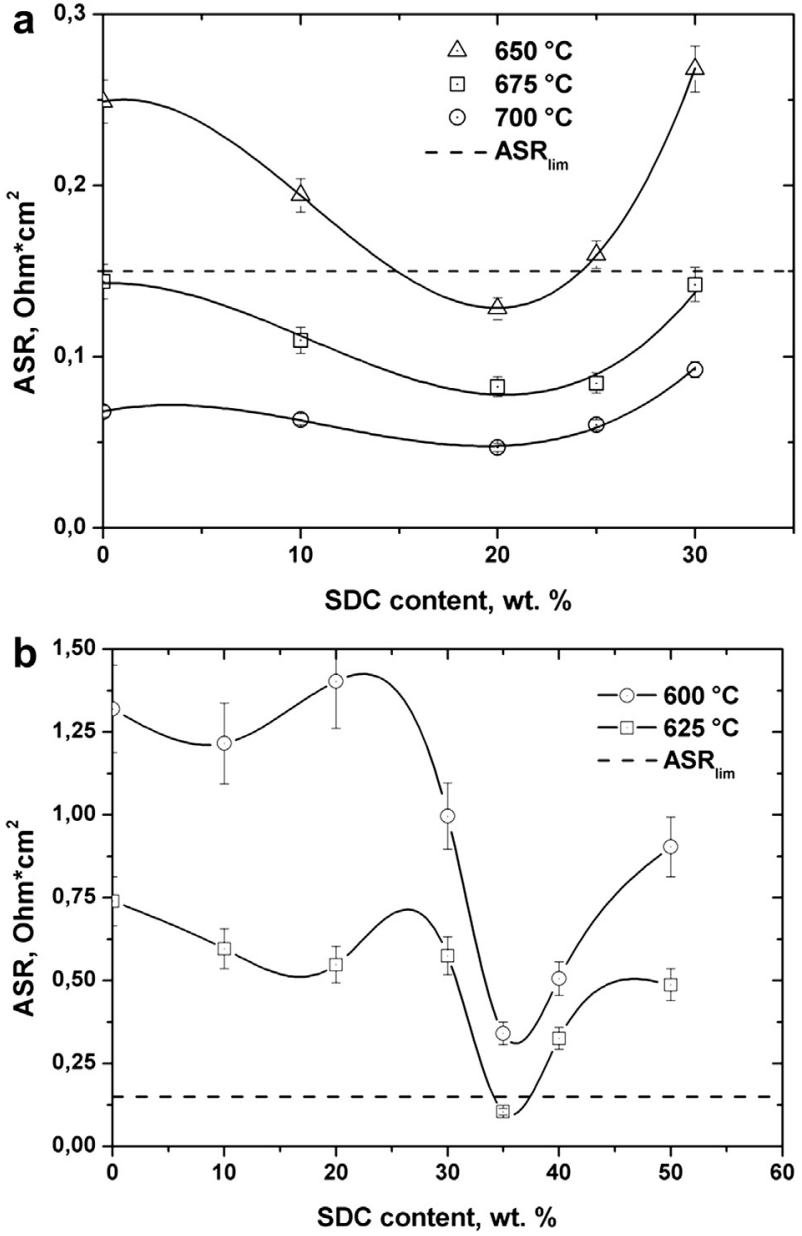

Fig. 8. Plot of ASR of composite cathodes vs. $\mathrm{Ce}_{0.8} \mathrm{Sm}_{0.2} \mathrm{O}_{2}$ ( $\equiv \mathrm{SDC}$ ) content at different temperatures: (a) $(100-y) \quad \mathrm{GdBaCo}_{2} \mathrm{O}_{6-\delta}-y \quad \mathrm{Ce}_{0.8} \mathrm{Sm}_{0.2} \mathrm{O}_{2} ; \quad$ (b) $(100-y)$ $\mathrm{GdBaCo}_{1.8} \mathrm{Fe}_{0.2} \mathrm{O}_{6-\delta}-y \mathrm{Ce}_{0.8} \mathrm{Sm}_{0.2} \mathrm{O}_{2}$.

The ASR behavior observed can be explained on the basis of the percolation theory. According to this theory, there is a critical value of the volume concentration of electronic or ionic conducting particles in a composite, i.e. percolation threshold, $\varphi$, [27,28], which corresponds to the formation of a 3D-network of these particles. Such a reticular structure extends the electrochemically active surface of electrode and, consequently, improves the cathode electrochemical activity. Theoretical calculations show that the percolation threshold of both types of particles depends on the ratio of their radii [27]. What is why, the grain-size analysis of double perovskite and solid electrolyte powders was carried out in the present work. The ratio of the particles radii, $P$, was calculated as

$P=\frac{d_{D P}}{d_{S E}}$

where $d_{D P}$ and $d_{S E}$ are the average diameters of double perovskite and solid electrolyte particles, respectively. The average diameters determined from particle size distribution curves were found to be equal to 4.152, 4.994 и $2.573 \mu \mathrm{m}$ for SDC, GBC and GBCF02, respectively. The theoretical percolation threshold for SDC was estimated according to Ref. [27] using ratio $P$ calculated as mentioned above. The experimental percolation threshold was accepted as the volume fraction of SDC solid electrolyte corresponding to the minimum value of ASR of composite cathode materials. Both theoretical and experimental values of $\varphi_{\mathrm{SDC}}$ as well as 
Table 2

Percolation threshold of $(100-y) \mathrm{GdBaCo}_{2-x} \mathrm{Fe}_{x} \mathrm{O}_{6-\delta}(x=0,0.2)-y \mathrm{Ce}_{0.8} \mathrm{Sm}_{0.2} \mathrm{O}_{2}$ $(y=10-50 \mathrm{wt} . \%)$ composite cathodes.

\begin{tabular}{|c|c|c|c|}
\hline Composite cathode & $P$ & $\begin{array}{l}\varphi \\
\text { (experimental) }\end{array}$ & $\begin{array}{l}\varphi \\
\text { (theoretical) }\end{array}$ \\
\hline $\begin{array}{l}(100-y) \mathrm{GdBaCo}_{2} \mathrm{O}_{6-\delta}-y \\
\mathrm{Ce}_{0.8} \mathrm{Sm}_{0.2} \mathrm{O}_{2}\end{array}$ & 1.20 & 0.20 & 0.25 \\
\hline $\begin{array}{l}(100-y) \mathrm{GdBaCo}_{1.8} \mathrm{Fe}_{0.2} \mathrm{O}_{6-\delta}-y \\
\mathrm{Ce}_{0.8} \mathrm{Sm}_{0.2} \mathrm{O}_{2}\end{array}$ & 0.62 & 0.35 & 0.40 \\
\hline
\end{tabular}

the ratio $P$ of the particles diameters are presented in Table 2 . As follows the theoretical and experimental values coincide with each other really good. Some difference in the values can be explained by two reasons. First of all, it is usually assumed within the framework of percolation micro-models that electron and ion conducting particles are spherical in shape with defined diameter. This is not the case for real particles which, as a rule, have complex shape with the size distributed around a mean value. Secondly, two components of the composite are usually treated as pure electronic or ionic conductor whereas the double perovskites $\mathrm{GdBaCO}_{2-x} \mathrm{Fe}_{x} \mathrm{O}_{6-\delta}$ are mixed ionic and electronic conductors.

Taking into account the target value of ASR as $0.15 \mathrm{Ohm}^{*} \mathrm{~cm}^{2}$ [29] the operation temperature of IT-SOFCs with SDC electrolyte and cathodes $80 \mathrm{GBC}-20$ SDC or 65 GBCF02 - 35 SDC composites can be estimated as $641{ }^{\circ} \mathrm{C}$ or $617^{\circ} \mathrm{C}$, respectively, what is significantly lower than one for the cathodes based on the undoped GBC $\left(668{ }^{\circ} \mathrm{C}\right)$ or the iron-doped GBCF02 $\left(697{ }^{\circ} \mathrm{C}\right)$ double perovskites. Thus SDC addition in the cathode material based on the double perovskite allows to reduce its TEC value as well as to lower operating temperature of IT-SOFC device. As a consequence, SDC addition up to certain extent enhances the cathode performance significantly.

\section{Conclusions}

The double perovskites $\mathrm{GdBaCo}_{2-x} \mathrm{Fe}_{x} \mathrm{O}_{6-\delta}(x=0,0.2)$ and composites $(100-y) \mathrm{GdBaCO}_{2-x} \mathrm{Fe}_{x} \mathrm{O}_{6-\delta}(x=0,0.2)-y$ $\mathrm{Ce}_{0.8} \mathrm{Sm}_{0.2} \mathrm{O}_{2}$ ( $y=10-50$ wt.\%) were prepared and investigated as cathode materials for IT-SOFCs. Partial substitution of Fe for Co was shown to lead to decreasing double perovskite $\mathrm{GdBaCo}_{2-\mathrm{x}} \mathrm{Fe}_{\mathrm{x}} \mathrm{O}_{6-}$ $\delta$ reactivity with the solid electrolyte $\mathrm{Ce}_{0.8} \mathrm{Sm}_{0.2} \mathrm{O}_{2}$. Average TEC and overall conductivity of the composite cathodes were found to descend with increasing solid electrolyte content. Polarization resistance of cathodes studied was shown to depend significantly on firing temperature. The optimal value of firing temperature for $\mathrm{GdBaCO}_{2-x} \mathrm{Fe}_{x} \mathrm{O}_{6-\delta}(x=0,0.2)$ cathodes was found to be about $1000{ }^{\circ} \mathrm{C}$. Variation of solid electrolyte content in $(100-y)$ $\mathrm{GdBaCo}_{2-x} \mathrm{Fe}_{x} \mathrm{O}_{6-\delta}(x=0,0.2)-y \mathrm{Ce}_{0.8} \mathrm{Sm}_{0.2} \mathrm{O}_{2}(y=10-50$ wt.\%) composites was shown to enable optimization of their electrochemical performance. Cathode materials of $80 \mathrm{wt} . \% \mathrm{GdBaCo}_{2} \mathrm{O}_{6-\delta}$ - 20 wt.\% $\mathrm{Ce}_{0.8} \mathrm{Sm}_{0.2} \mathrm{O}_{2}$ and 65 wt.\% $\mathrm{GdBaCo}_{1.8} \mathrm{Fe}_{0.2} \mathrm{O}_{6-\delta}-35$ wt.\%
$\mathrm{Ce}_{0.8} \mathrm{Sm}_{0.2} \mathrm{O}_{2}$ were shown to have the lowest ASR which is less than target value of $0.15 \mathrm{Ohm}^{*} \mathrm{~cm}^{2}$ and the reasonable TEC values and, therefore, can be considered as promising cathode materials for ITSOFCs.

\section{Acknowledgments}

This work was supported by the Russian Foundation for Basic Research grant No. 12-03-91663-ERA_a.

\section{References}

[1] A. Chang, S.J. Skinner, J.A. Kilner, Solid State Ionics 177 (2006) 2009-2011.

[2] A. Tarancón, A. Morata, G. Dezanneau, S.J. Skinner, J.A. Kilner, S. Estradé, F. Hernández-Ramírez, F. Peiró, J.R. Morante, Journal of Power Sources 174 (2007) 255-263.

[3] N. Li, Z. Lü, B. Wei, X. Huang, K. Chen, Y. Zhang, W. Su, Journal of Alloys and Compounds 454 (2008) 274-279.

[4] Q. Zhou, T. He, Y. Ji, Journal of Power Sources 185 (2008) 754-758.

[5] J.H. Kim, Y. Kim, P.A. Connor, J.Y. Irvine, J. Bae, Journal of Power Sources 194 (2009) 704-711.

[6] D. Chen, R. Ran, K. Zhang, J. Wang, Z. Shao, Journal of Power Sources 188 (2009) 96-105.

[7] D.S. Tsvetkov, V.V. Sereda, A.Yu. Zuev, Solid State Ionics 180 (2010) 16201625.

[8] D.S. Tsvetkov, V.V. Sereda, A.Yu. Zuev, Solid State Ionics 192 (2011) 215-219.

[9] A.A. Taskin, A.N. Lavrov, Y. Ando, Progress in Solid State Chemistry 35 (2007) 481-490.

[10] A. Tarancón, D. Marrero-López, J. Peña-Martínez, J.C. Ruiz-Morales, P. Núñez, Solid State Ionics 179 (2008) 611-618.

[11] J. Peña-Martínez, A. Tarancón, D. Marriero-López, J.C. Ruiz-Morales, P. Núñez, Fuel Cells 5 (2008) 351-359.

[12] Y. Lee, D.Y. Kim, G.M. Choi, Solid State Ionics 192 (2011) 527-530.

[13] B. Wei, Z. Lü, D. Jia, X. Huang, Y. Zhang, W. Su, International Journal of Hydrogen Energy 35 (2010) 3775-3782.

[14] S.J. Lee, D.S. Kim, D.K. Kim, Current Applied Physics 11 (2011) S238-S241.

[15] K. Zhang, L. Ge, R. Ran, Z. Shao, S. Liu, Acta Materialia 56 (2008) 48764889.

[16] D. Chen., R. Ran, Z. Shao, Journal of Power Sources 195 (2010) 7187-7195

[17] L. Zhao, Q. Nian, B. He, B. Lin, H. Ding, S. Wang, Journal of Power Sources 195 (2010) 453-456.

[18] C. Zhu, X. Liu, C. Yi, L. Pei, D. Wang, D. Yan, K. Yao, T. Lü, W. Su, Journal of Power Sources 195 (2010) 3504-3507.

[19] Q. Zhou, F. Wang, Y. Shen, T. He, Journal of Power Sources 195 (2010) $2174-$ 2181.

[20] S. Lü, G. Long, Y. Ji, X. Meng, C. Sun, International Journal of Hydrogen Energy 35 (2010) 7930-7935.

[21] N. Li, B. Wei, Z. Lü, X. Huang, W. Su, Journal of Alloys and Compounds 509 (2011) 3651-3655.

[22] A.N. Petrov, A.Yu. Zuev, A.I. Vylkov, Russian Journal of Physical Chemistry 79 (2005) 220

[23] A. Tarancón, J. Peña-Martínez, D. Marrero-López, A. Morata, J.C. Ruiz-Morales, P. Núñez, Solid State Ionics 179 (2008) 2372-2378.

[24] G.A. Tompsett, N.M. Sammes, O. Yamamoto, Journal of the American Ceramic Society 80 (1997) 3181-3186.

[25] D.S. Tsvetkov, N.S. Saricheva, V.V. Sereda, A.Yu. Zuev, Journal of Fuel Cell Science and Technology 8 (2011), 041006-1-041006-4.

[26] D.S. Tsvetkov. PhD thesis, Ural State University, Ekaterinburg, 2010.

[27] P. Costamagna, P. Costa, V. Antonucci, Electrochimica Acta 43 (1998) 375-394.

[28] D. Chen, Z. Lin, H. Zhu, R.J. Kee, Journal of Power Sources 191 (2009) $240-252$.

[29] N.P. Brandon, S. Skinner, B.C.H. Steele, Annual Review of Materials Reserach 33 (2003) 183-213. 